\title{
Correlation between chemical composition and antibacterial activity of some Lamiaceae species essential oils from Tunisia
}

Sarra Moumni ${ }^{1^{*}}$, Ameur Elaissi ${ }^{1}$, Amine Trabelsi ${ }^{2}$, Abderrahmen Merghni ${ }^{3}$, Imed Chraief ${ }^{4}$, Brahim Jelassi ${ }^{5}$, Rachid Chemli ${ }^{2}$ and Salima Ferchichi ${ }^{6}$

\begin{abstract}
Background: Lamiaceae family is one of the most diverse and common plant families in terms of ethnomedicine due to their potential therapeutic effects. The aim of this study is to investigate the correlation between the chemical composition and the antibacterial effect of five essential oils from this family against five reference bacterial strains responsible of nosocomial diseases and foodborne illnesses.

Methods: The commercial essential oils of Tunisian Rosmarinus officinalis, Thymus capitatus, Origanum majorana and Salvia officinalis were analyzed by GC/FID and GC-MS. Essential oils were evaluated for their antibacterial activities by disc diffusion and microbroth dilution methods against five reference bacterial strains: Pseudomonas aeruginosa, Escherichia coli, Salmonella enterica, Bacillus subtilis and Staphylococcus aureus. The inhibition zone diameter values and the twenty major compounds of the selected essential oils were subjected to PCA and HCA analysis.

Results: Analysis by GC/FID and GC/MS allowed the identification of ninety-one components representing 96.0 to $98.2 \%$ of the total oils. The different component contents varied according to the species. The main components were carvacrol, 1,8-cineole, $a$-thujone, $a$-terpineol and $a$-pinene. The PCA and the HCA of the selected essential oil components and the inhibition zone diameter (IZD) values identified four species groups and subgroups. Each essential oils group constituted a chemotype responsible for their bacterial inhibition ability. Thymus capitatus essential oil showed the strongest antibacterial activity with $\mathrm{MBC}$ ranging from 0.73 to $2.94 \mathrm{mg} \mathrm{mL}^{-1}$.

Conclusion: Rosmarinus officinalis, Thymus capitatus, Origanum majorana and Salvia officinalis essential oils have shown promising antibacterial activities against reference bacterial strains responsible for nosocomial diseases and foodborne illnesses.
\end{abstract}

Keywords: Lamiaceae family, Essential oils, Chemical composition, Antibacterial activity, Principal component analysis (PCA), Hierarchical cluster analysis (HCA)

\footnotetext{
* Correspondence: sarra.moumniessahli@gmail.com

'Laboratory of Chemical, Pharmaceutical and Pharmacological Drug

Development LR12ES09, Faculty of Pharmacy, University of Monastir, rue Avicenne, 5000 Monastir, Tunisia

Full list of author information is available at the end of the article
}

(c) The Author(s). 2020 Open Access This article is licensed under a Creative Commons Attribution 4.0 International License, which permits use, sharing, adaptation, distribution and reproduction in any medium or format, as long as you give appropriate credit to the original author(s) and the source, provide a link to the Creative Commons licence, and indicate if changes were made. The images or other third party material in this article are included in the article's Creative Commons. licence, unless indicated otherwise in a credit line to the material. If material is not included in the article's Creative Commons licence and your intended use is not permitted by statutory regulation or exceeds the permitted use, you will need to obtain permission directly from the copyright holder. To view a copy of this licence, visit http://creativecommons.org/licenses/by/4.0/ The Creative Commons Public Domain Dedication waiver (http://creativecommons.org/publicdomain/zero/1.0/) applies to the data made available in this article, unless otherwise stated in a credit line to the data. 


\section{Background}

In the last few years, the interest in natural medicine has been increasing in industrialized societies particularly against microbial agents because of the ever growing problem of antibiotic resistance [1]. Natural products are an important source of novel and chemically diverse molecules for drug discovery [2]. In fact, because of their bioactive compounds and their antimicrobial properties, the interest in medicinal plants has increased considerably [3]. Actually, 69\% of currently employed antibiotics are derived from natural products [4]. Essential oils are volatile fractions obtained from medicinal and aromatic plants, they have been screened for their potential uses as alternative remedies for the treatment of many infections and as natural food preservatives [5-8]. Lamiaceae family is one of the most diverse and widespread plant families in term of ethnomedicine and its medicinal value is mainly based on the volatile oils composition [9]. It was reported that the leaves of $T$. capitatus were used for many purposes such as unguents for embalming by Egyptians [10], antispasmolytic, antiseptic, expectorant, anti-ulcers, anti-dermatitis and rheumatic pains [11]. T. capitatus showed good results in treatment of skin diseases and as tonic and antitussive agent [12]. S. officinalis is used for its antibacterial [13, 14], antiviral [15] and antioxidant [16] activities. It is also used as a flavoring agent in perfumery and cosmetics [17]. $R$. officinalis has been traditionally used for both medical and culinary purposes [18]. Indeed, the whole fresh plant or its dried milled powder is used as a food flavoring and preservative agent [19]. Likewise, $R$. officinalis is known as a medicinal herb with significant activities against many illnesses especially against headaches, respiratory diseases and several neuropsychiatric disorders, according to traditional Tunisian medicine [20]. O. majorana L. is used as a medicinal plant; it has traditionally been used as stimulant, condiment, and tonic [21]. In addition, O. majorana L. essential oil is used for its antibacterial [22] and antioxidant activities [21].

Because of their interesting physicochemical characteristics of substantial value, the Lamiaceae essential oils have garnered research and industrial interests for their use as natural products [23]. However, in Tunisia, apart from $R$. officinalis EO, Lamiaceae EOs production is still weak despite the plants abundance and scientific researches on these EOs bioactivities [14, 24, 25]. Essential oils chemical composition is affected by several factors, including the species, part of the plant, season of harvesting, geographical origin, and also the extraction method and conditions which consequently impact on their bioactive properties [26-29]. Hence, the present work aimed to study the chemical composition of five commercial Lamiaceae EOs from Tunisian provenance and their antibacterial effects against five pathogen bacteria models. A correlation between 20 major compounds and their antibacterial ability was investigated.

\section{Methods \\ Essential oils}

EO samples were offered by three Tunisian companies specialized in EO extraction: Bio Orient (S. officinalis and T. capitatus), Agriland ( $R$. officinalis ${ }_{1}$ and O. majorana) and Uticafloria ( $R$. officinalis $\left.{ }_{2}\right)$. S. officinalis was collected from Sfax $\left(34^{\circ} 44^{\prime} \mathrm{N}, 10^{\circ} 46^{\prime} \mathrm{E}\right)$ in the southeast of Tunisia. T. capitatus was harvested from Sejnane $\left(37^{\circ} 03^{\prime} 23^{\prime \prime} \mathrm{N}, 9^{\circ} 14^{\prime} 18^{\prime \prime} \mathrm{E}\right)$ in the northwest of Tunisia. $O$. majorana was collected from Zaghouan $\left(36^{\circ} 24^{\prime} \mathrm{N}\right.$, $\left.10^{\circ} 09^{\prime} \mathrm{E}\right)$ in the north of Tunisia. R. officinalis ${ }_{1}$ was collected from Sbikha $\left(35^{\circ} 56^{\prime} \mathrm{N}, 10^{\circ} 01^{\prime} \mathrm{E}\right)$ in the center of Tunisia. $R$. officinalis 2 was harvested from El Fahs $\left(36^{\circ} 23^{\prime} \mathrm{N}, 9^{\circ} 54^{\prime} \mathrm{E}\right)$ in the north of Tunisia. Botanical voucher specimens have been identified by Professor Ameur ELAISSI and deposited with the herbarium of the Pharmacognosy Loboratory in Faculty of Pharmacy, Monastir, Tunisia, under the following references: 0181, 0182, 0183, 0184 and 0185.

The essential oils were extracted by hydrodistillation of fresh aerial parts. For each species, 3 Samples of the obtained EO were stored at $4{ }^{\circ} \mathrm{C}$ until analysis was attempted.

\section{Chemical analysis}

Quantitative and qualitative data of all the essential oils were determined in triplicate by GC/FID and GC/MS respectively.

\section{Gas chromatography analysis}

One microliter sample of $10 \%$ solution of essential oil in purified hexane was injected for analysis using a HP 6890 chromatography apparatus equipped with flame ionization detector (FID) and HP5 column $(30 \mathrm{~m} \times 0.25 \mathrm{~mm}$, film thickness $0.25 \mu \mathrm{m})$. The analytical conditions were as follows: injector and detector temperature were maintained at $250^{\circ} \mathrm{C}$ and $280^{\circ} \mathrm{C}$ respectively. Oven temperature was programmed to rise from $60{ }^{\circ} \mathrm{C}$ to $250{ }^{\circ} \mathrm{C}$ at $5{ }^{\circ} \mathrm{C} / \mathrm{min}$, isothermal temperature $60^{\circ} \mathrm{C}$ for $1 \mathrm{~min}$ and $250^{\circ} \mathrm{C}$ for $3 \mathrm{~min}$; carrier gas was $\mathrm{N}_{2}$ with a flow rate of $1.2 / \mathrm{min}$. The software HP Chemstation, allowing assimilation of the percentages of the peak areas to the percentages of the various constituents was used to calculate relative concentration. Kovats retention Indexes (KI) were obtained by running a series of aliphatic hydrocarbons (C9-C28) increasing number order of carbon atoms on the column.

\section{Gas chromatography-mass-spectrometry analysis}

The essential oils analysis was performed using a Hewlett Packard (HP) 5890 II GC equipped with a HP-5MS capillary column $(30 \mathrm{~m} \times 0.25 \mathrm{~mm}$, film thickness $0.25 \mu \mathrm{m})$ and 
a HP 5972 mass selective detector. Helium was used as the carrier gas at a flow rate of $1.2 \mathrm{ml} / \mathrm{min}$. For GC/MS detection, an electron ionization system, with ionization energy of $70 \mathrm{eV}$, a scan time of $1.5 \mathrm{~s}$ and mass range 40$300 \mathrm{amu}$ was used. The GC/MS parameters were identical to those for the GC/FID analysis.

\section{Compound identification}

The compounds were identified by comparing retention indices (determined relatively to the retention time of aliphatic hydrocarbons (C9-C28)) of the mass spectra with those of authentic compounds by means of Wiley 275.L, 6th edition mass spectral library and NBS75K.L data bases. The identification is confirmed by comparing their retention indices with data published in the literature $[30,31]$.

\section{Antibacterial assay \\ Bacterial strains}

Three Gram negative bacteria (Gram (-)), Pseudomonas aeruginosa (CIP 82118), Salmonella enterica (CIP 80.39), Escherichia coli (CIP 53.126) and two Gram positive (gram (+)) bacteria Staphylococcus aureus (CIP 4.83) and Bacillus subtilis (CIP 52.62) were used to carry out this study. Microorganisms were obtained from the culture collection of the laboratory of transmissible diseases and biologically active substances, Faculty of Pharmacy, Monastir, Tunisia.

\section{Agar disk diffusion method}

To evaluate the antibacterial activity of the selected EOs, the agar disk diffusion assay [32] was carried out. Overnight cultures $\left(24 \mathrm{~h}\right.$ at $37^{\circ} \mathrm{C}$ ) in $\mathrm{MH}$ broth were prepared. The bacterial inocula were obtained by diluting the overnight cultures in Mueller Hinton Broth medium to adjust the optical density at approximately $0.5 \mathrm{Mc}$ Farland standards. Absorbent discs (Whatman disc No.3, $6 \mathrm{~mm}$ diameter) were impregnated with $10 \mu \mathrm{L}$ of essential oil and then placed on the surface of inoculated Petri dishes. Positive control discs of standard antibiotic GENTAMICIN $^{\otimes}(10 \mu \mathrm{g} /$ disc $)$ were tested. After $24 \mathrm{~h}$ of incubation at $37^{\circ} \mathrm{C}$, the inhibition zones were measured and expressed in $\mathrm{mm}$. All experiments were performed in triplicate.

\section{Minimum inhibitory and minimum bactericidal concentrations}

For each essential oil, the minimum inhibitory concentration (MIC) and minimum bactericidal concentration (MBC) values against the bacterial strains were determined according to the National committee for clinical Laboratory Standard [33]. An overnight culture $\left(37^{\circ} \mathrm{C}\right)$ in Mueller Hinton broth medium of the tested strains was prepared by adjusting the turbidity of each bacterial culture to reach an optical density of 0.5 Mc Farland standards.

The broth dilution method was carried out in 96-well microtitre plates using bacterial reference strains. To obtain stable diffusion, EOs stock solutions were prepared aseptically in DMSO $(80,20 \%, \mathrm{v} / \mathrm{v})$, transferred to sterile 96-well microtitre plates containing the Mueller Hinton medium and then diluted by two-fold serial dilution. Ten microliter of each strain inoculum was added to each well. Negative control wells contained only bacteria in the $\mathrm{MH}$ broth medium. Positive control wells contained $10 \mu \mathrm{g} \mathrm{mL}^{-1}$ Gentamicin $^{\ominus}$ antibiotic. After incubation for $24 \mathrm{~h}$ at $37^{\circ} \mathrm{C}, 10 \mu \mathrm{L}$ of $0.02 \%(\mathrm{p} / \mathrm{v})$ resazurin solution was added. Bacterial growth was evaluated by the observation of the wells color change from blue to pink. The MIC was defined as the lowest concentration that completely inhibit visible cell growth during a $24 \mathrm{~h}$ incubation at $37^{\circ} \mathrm{C}$ (blue colored). DMSO 20\% (v/v) had no inhibition effect. To determine the minimum bactericidal concentration (MBC) values, $10 \mu \mathrm{L}$ of each well with no visible growth were removed and inoculated in $\mathrm{MH}$ plates. After $24 \mathrm{~h}$ of incubation at $37^{\circ} \mathrm{C}$, the number of surviving organisms was determined. $\mathrm{MBC}$ was defined as the lowest concentration at which $99 \%$ of the bacteria were killed. The experiments were performed in triplicate.

\section{Statistical analysis}

The data were subjected to statistical analysis using analysis of variance (ANOVA), and the significance of the difference between means was assumed at $p \leq 0.05$ using Student Newman and Keuls (SNK) test. Twenty Compounds detected in the essential oil samples at an average concentration greater than $3.0 \%$ were selected and used to evaluate whether the identified compounds may be useful in reflecting chemotaxonomic and biological activities relationships. Data of antibacterial activity and components were subjected to principal components (PCA) and hierarchical cluster analysis (HCA). Statistical tests were performed using $\mathrm{IBM}^{\odot} \mathrm{SPSS}^{\bullet} 20$ software (SPSS INC.Chicago,IL, USA).

\section{Results}

\section{Chemical composition}

The essential oils of $T$. capitatus, S. officinalis, $R$. officinalis $_{1}, R$. officinalis 2 , and O. majorana were subjected to the chromatographic analyses (GC/FID and GC/MS). Ninety-one components representing 96.0 to $98.2 \%$ of the total oils content were identified (Table 1). The identified components were divided in to eleven chemical classes (Table 1). The monoterpene phenols $(1.02 \pm 0.4-$ $56.6 \pm 2.8 \%$ ) constituted the main class with carvacrol (tr $-56.1 \pm 3.0 \%$ ), as major constituent of T. capitatus EO. The class with the second highest contents was 
Table 1 Chemical composition of S. officinalis, T. capitatus, R. officinalis ${ }_{1}, R$. officinalis 2 and O. majorana essential oils

\begin{tabular}{|c|c|c|c|c|c|c|}
\hline & $K^{(a)}$ & Composition & & & & \\
\hline & & S. officinalis & T. capitatus & R. officinalis, & R. officinalis ${ }_{2}$ & O. majorana \\
\hline Tricyclene & 923 & 0.5 & -b) & 0.1 & 0.2 & - \\
\hline$a$-Thujene & 927 & 0.4 & 1.0 & 0.1 & 0.1 & 1.0 \\
\hline a-Pinene & 934 & 6.2 & 0.8 & 7.0 & 19.4 & 1.1 \\
\hline Camphene & 949 & 6.2 & 0.2 & 2.7 & 6.5 & 0.2 \\
\hline Sabinene & 974 & 0.1 & - & 0.1 & $\operatorname{Tr}^{c)}$ & 2.2 \\
\hline$\beta$-Pinene & 978 & 2.6 & 0.5 & 4.6 & 3.6 & 0.6 \\
\hline$\beta$-Myrcene & 992 & 0.8 & 1.9 & - & 0.1 & 1.5 \\
\hline a-Phellandrene & 1002 & $\operatorname{Tr}$ & 0.3 & - & 1.8 & 0.4 \\
\hline$\delta$-3-Carene & 1006 & $\operatorname{Tr}$ & 0.1 & 0.2 & 0.2 & 0.2 \\
\hline$a$-Terpinene & 1012 & 0.1 & 2.0 & 0.1 & 0.4 & 7.7 \\
\hline p-Cymene & 1025 & 2.1 & 7.4 & 1.9 & 0.9 & 9.7 \\
\hline Limonene & 1029 & 1.6 & 0.5 & - & 2.5 & - \\
\hline 1.8-Cineole & 1032 & 10.3 & 2.9 & 47.2 & 37.6 & 4.0 \\
\hline (Z)- $\beta$-Ocimene & 1038 & $\operatorname{Tr}$ & $\operatorname{Tr}$ & $\operatorname{Tr}$ & 0.1 & - \\
\hline$(E)$ - $\beta$-Ocimene & 1048 & $\operatorname{Tr}$ & 0.1 & $\operatorname{Tr}$ & 0.1 & - \\
\hline$\gamma$-Terpinene & 1058 & 0.6 & 10.8 & 0.3 & 0.5 & 16.3 \\
\hline (Z)-Sabinene hydrate & 1068 & $\operatorname{Tr}$ & 0.6 & 0.1 & - & 1.9 \\
\hline (Z)-Linalool oxyde furanoid & 1070 & - & $\operatorname{Tr}$ & - & - & - \\
\hline$a$-Terpinolene & 1090 & 0.3 & 0.2 & 0.3 & 0.3 & $\operatorname{Tr}$ \\
\hline (E)-Sabinene hydrate & 1098 & - & 1.1 & - & - & 3.7 \\
\hline Linalool & 1101 & - & 0.5 & 1.0 & 0.5 & 2.8 \\
\hline (E)-4-Thujanol & 1104 & - & - & - & - & 1.1 \\
\hline a-Thujone & 1109 & 22.8 & - & $\operatorname{Tr}$ & 0.1 & - \\
\hline$\beta$-Thujone & 1119 & 6.8 & - & 0.1 & $\operatorname{Tr}$ & - \\
\hline (Z)-2-Menth-2en-ol & 1124 & - & - & - & - & 0.8 \\
\hline a-Campholenal & 1127 & $\operatorname{Tr}$ & - & $\operatorname{Tr}$ & $\operatorname{Tr}$ & - \\
\hline (E)-Menth-2-en-ol & 1142 & - & - & - & - & 0.8 \\
\hline Camphor & 1146 & 19.3 & 1.6 & 13.3 & 7.1 & $\operatorname{Tr}$ \\
\hline Isoborneol & 1158 & - & - & $\operatorname{Tr}$ & $\operatorname{Tr}$ & - \\
\hline Pinocarvone & 1160 & - & $\operatorname{Tr}$ & - & - & - \\
\hline Borneol & 1167 & 4.0 & 1.0 & 5.4 & 4.4 & - \\
\hline (Z)-Pinocamphone & 1175 & $\operatorname{Tr}$ & - & - & - & - \\
\hline Terpinen-4-ol & 1178 & 0.4 & 0.8 & 1.0 & 0.5 & 0.3 \\
\hline p-Cymen-8-ol & 1186 & 0.1 & $\operatorname{Tr}$ & 0.1 & $\operatorname{Tr}$ & - \\
\hline$a$-Terpineol & 1192 & 0.1 & 0.2 & 2.6 & 1.6 & 27.4 \\
\hline Myrtenal & 1198 & 0.1 & - & - & - & - \\
\hline Myrtenol & 1205 & $\operatorname{Tr}$ & - & - & - & 0.3 \\
\hline (E)-Dihydrocarvone & 1206 & - & $\operatorname{Tr}$ & - & - & - \\
\hline Verbenone & 1207 & - & - & $\operatorname{Tr}$ & $\operatorname{Tr}$ & 3.7 \\
\hline (Z)-Sabinene hydrate acetate & 1211 & - & - & - & - & 0.4 \\
\hline Compound class and name & & & & & & \\
\hline endo-Fenchyl acetate & 1221 & $\operatorname{Tr}$ & - & - & - & - \\
\hline Nerol & 1229 & - & - & - & - & $\operatorname{Tr}$ \\
\hline
\end{tabular}


Table 1 Chemical composition of S. officinalis, T. capitatus, R. officinalis $s_{1}, R$. officinalis ${ }_{2}$ and O. majorana essential oils (Continued)

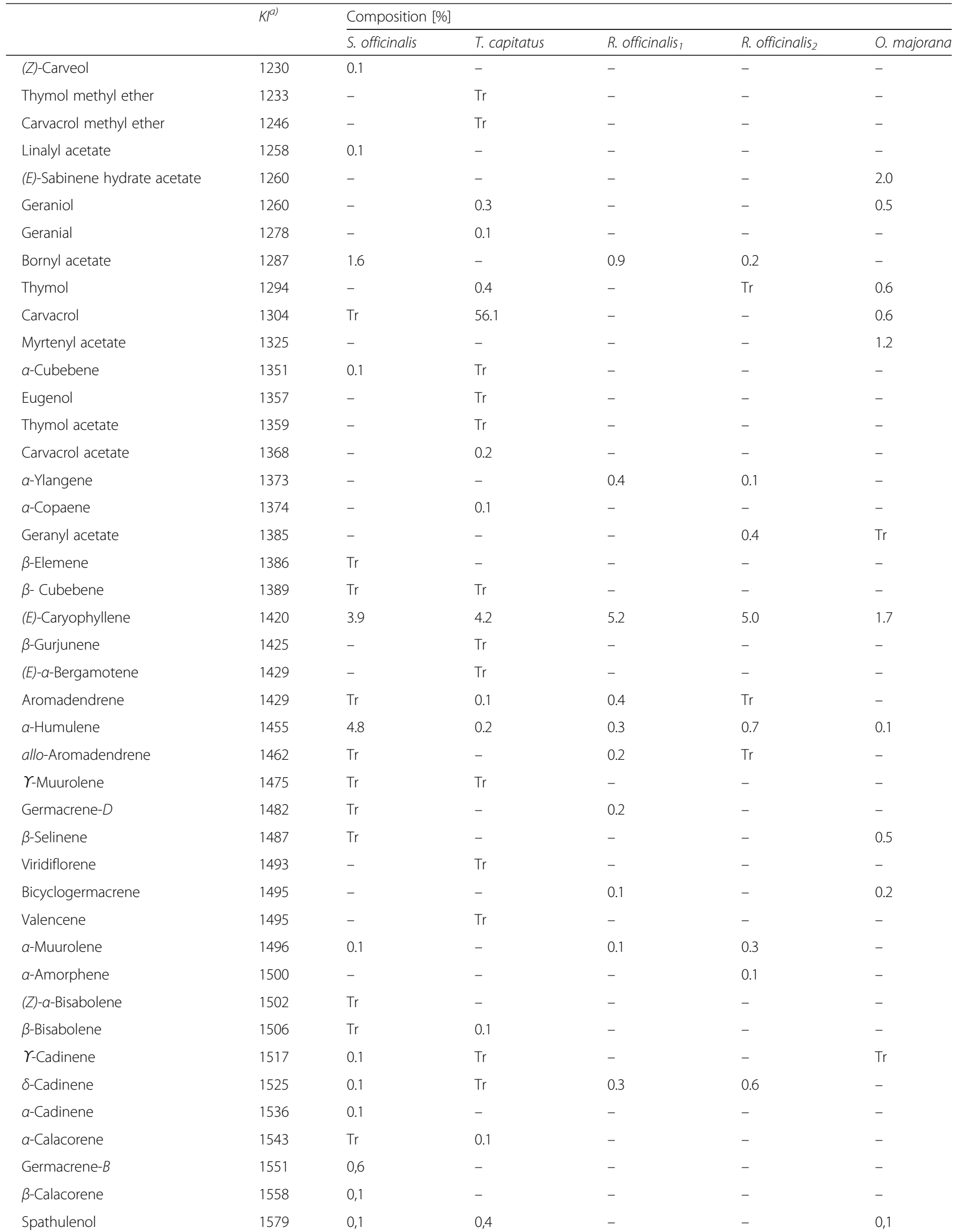


Table 1 Chemical composition of S. officinalis, T. capitatus, R. officinalis ${ }_{1}$, R. officinalis 2 and O. majorana essential oils (Continued)

\begin{tabular}{|c|c|c|c|c|c|c|}
\hline & \multirow[t]{2}{*}{$K^{(a)}$} & \multicolumn{5}{|c|}{ Composition [\%] } \\
\hline & & S. officinalis & T. capitatus & R. officinalis, & R. officinalis 2 & O. majorana \\
\hline Caryophyllene oxide & 1584 & 0,5 & 0,3 & 0,2 & 0,1 & 0,4 \\
\hline Vidiflorol & 1593 & $\operatorname{Tr}$ & - & - & $\operatorname{Tr}$ & - \\
\hline epi-a-Cadinol & 1640 & $\operatorname{Tr}$ & $\operatorname{Tr}$ & - & - & - \\
\hline T-Muurolol & 1644 & $\operatorname{Tr}$ & - & - & - & - \\
\hline a-Muurolol & 1652 & $\operatorname{Tr}$ & - & - & - & - \\
\hline a-Cadinol & 1656 & $\operatorname{Tr}$ & - & - & - & - \\
\hline Monoterpene hydrocarbons & & $21.6 \pm 6.1^{\mathrm{ab}}$ & $25.7 \pm 5.5^{\mathrm{abc}}$ & $17.5 \pm 6.6^{\mathrm{a}}$ & $36.8 \pm 9.7^{\mathrm{bc}}$ & $40.9 \pm 5.2^{c}$ \\
\hline Monoterpene oxides & & $10.3 \pm 1.4^{\mathrm{b}}$ & $2.9 \pm 4.6^{\mathrm{a}}$ & $47.2 \pm 0.5^{d}$ & $37.6 \pm 0.5^{c}$ & $4.0 \pm 0.5^{\mathrm{a}}$ \\
\hline Monoterpene alcohols & & $4.7 \pm 0.3^{a}$ & $4.6 \pm 1.0^{\mathrm{a}}$ & $10.2 \pm 2.8^{b}$ & $7.0 \pm 2.1^{\mathrm{ab}}$ & $39.6 \pm 3.1^{c}$ \\
\hline Monoterpene ketones & & $48.9 \pm 4.1^{c}$ & $1.7 \pm 2.8^{\mathrm{a}}$ & $13.5 \pm 2.9^{b}$ & $7.2 \pm 1.3^{\mathrm{a}}$ & $3.7 \pm 0.5^{\mathrm{a}}$ \\
\hline Monoterpene aldehydes & & $0.1 \pm 0.0^{\mathrm{a}}$ & $0.1 \pm 0.1^{\mathrm{a}}$ & $\operatorname{Tr}$ & $\operatorname{Tr}$ & - \\
\hline Monoterpene esters & & $1.7 \pm 0.2^{b}$ & $0.2 \pm 0.1^{\mathrm{a}}$ & $0.9 \pm 0.2^{a}$ & $0.6 \pm 0.3^{a}$ & $3.6 \pm 0.6^{c}$ \\
\hline Monoterpene ethers & & - & $0.1 \pm 0.1 \mathrm{a}$ & - & - & - \\
\hline Monoterpene phenols & & $\operatorname{Tr}$ & $56.6 \pm 2.8^{b}$ & $\operatorname{Tr}$ & - & $1.2 \pm 0.4^{a}$ \\
\hline Sesquiterpene hydrocarbons & & $10.0 \pm 3.3^{b}$ & $4.9 \pm 0.3^{\mathrm{ab}}$ & $7.1 \pm 1.0^{\mathrm{ab}}$ & $7.0 \pm 4.3^{\mathrm{ab}}$ & $2.5 \pm 0.6^{a}$ \\
\hline Sesquiterpene alcohols & & $0.3 \pm 0.2^{a}$ & $0.4 \pm 0.3^{a}$ & - & $\operatorname{Tr}$ & $0.1 \pm 0.1^{a}$ \\
\hline Sesquiterpene oxides & & $0.5 \pm 0.3^{a}$ & $0.3 \pm 0.4^{a}$ & $0.2 \pm 0.3^{a}$ & $0.1 \pm 0.1^{\mathrm{a}}$ & $0.4 \pm 0.1^{a}$ \\
\hline Not identified & & $1.8 \pm 0.5^{\mathrm{a}}$ & $2.8 \pm 0.8^{\mathrm{ab}}$ & $3.4 \pm 0.3^{\mathrm{ab}}$ & $3.6 \pm 1.4^{\mathrm{ab}}$ & $0.4 \pm 0.5^{b}$ \\
\hline Total identified & & 98.2 & 97.2 & 96.6 & 96.4 & 96.0 \\
\hline
\end{tabular}

${ }^{a}$ Kovats retention index determined on a HP5 capillary column. ${ }^{\mathrm{b}}$-: not detected. ${ }^{\mathrm{C}} \operatorname{Tr} \operatorname{Trace}(<0.1 \%)$

composed of monoterpene ketones $(1.7 \pm 2.8-48.9 \pm$ 4.1\%). S. officinalis essential oil was characterized by the highest content in this class, with $\alpha$-thujone $(0.1 \pm 0.0$ $22.8 \pm 1.5 \%)$ having the highest content in this species, followed by camphor $(1.61 \pm 2.7-19.3 \pm 2.1 \%)$ and $\beta$-thujone (tr $-6.8 \pm 0.5 \%)$. Verbenone ( $\operatorname{tr}-3.7 \pm 0.5$ ) have the highest content in O. majorana. The monoterpene oxides $(2.9 \pm 4.6-47.2 \pm 0.5 \%)$ represented the third major class, constituted by 1,8 -cineole $(2.9 \pm 4.6-47.2 \pm 0.5 \%)$, $R$. officinalis ${ }_{1}$ have the highest content while T. capitatus have the smallest one. The fourth major class was composed of monoterpene hydrocarbons (17.5 $\pm 6.6-40.9 \pm$ $5.2 \%), O$. majorana and $R$. officinalis s $_{2}$ were characterized by the highest mean percentages of this class $(40.9 \pm 5.2$ and $36.8 \pm 9.7 \%$, respectively). $\alpha$-pinene $(0.8 \pm 0.0-19.4 \pm$ $5.4 \%$ ) have the highest content in the essential oils of $R$. officinalis $_{1}, R$. officinalis 2 and S. officinalis. The second major component in this class, $\mathcal{Y}$-terpinene $(0.3 \pm 0.0-$ $16.3 \pm 1.5 \%)$, have the highest content in O. majorana and $T$. capitatus, these two species are characterized by the highest content of $p$-cymene $(0.9 \pm 1.0-9.7 \pm .8 \%)$. $O$. majorana is characterized by the highest content of $\alpha$ terpinene $(0.1 \pm 0.1-7.7 \pm 1.3 \%)$ however $R$. officinalis $s_{2}$ have the highest content of camphene $(0.2 \pm 0.0-6.5 \pm$ $1.6 \%)$. The major components of the fifth monoterpene alcohols class $(4.6 \pm 1.0-39.6 \pm 3.1 \%)$, were $\alpha$-terpineol $(0.1 \pm 0.0-27.4 \pm 2.8 \%)$ and borneol $(1.0 \pm 0.8-5.4 \pm 1.5)$.
The sixth class was sesquiterpene hydrocarbons $(2.5 \pm$ $0.6-10.0 \pm 3.3 \%)$ represented essentially by (E)-caryophyllene $(1.7 \pm 0.5-5.2 \pm 0.9 \%)$ which was more abundant in $R$. officinalis $E O$ samples, and $\alpha$-humulene $(0.1 \pm$ $0.0-4.8 \pm 2.0 \%$ ), characterizing $S$. officinalis EO.

Figure 1 shows the chemical structures of some of the main components.

\section{Principal component analysis (PCA) and hierarchical cluster analysis (HCA) Chemical classes}

The contents in different chemical classes for the five EOs was significantly different between the species $(p<$ 0.05). The PCA horizontal axis explained $34.12 \%$ of the total variance and the vertical $21.26 \%$ (Fig. 2). The HCA (Fig. 3) based on the Euclidean distances between groups indicated the presence of three groups $(A, B$ and $C)$ identified by their contents in different chemical classes with a dissimilarity $>15$. Group $C$ was divided in two Subgroups $\left(C_{1}\right.$ and $\left.C_{2}\right)$ with a dissimilarity $>5$. The two species $T$. capitatus and $O$. majorana stand out in both HCA and PCA analyses, forming separate groups, group $A$ and $B$, respectively. Group $A$ formed by $T$. capitatus which EO was distinguished by the highest content in monoterpene phenols $(56.6 \pm 2.8 \%)$ and the smallest contents in monoterpene alcohols $(4.6 \pm 1.0 \%)$, monoterpene oxides $(2.9 \pm 4.6 \%)$ and monoterpene ketones 


-Pinene

$(1.7 \pm 2.8 \%)$. Group B was represented by $O$. majorana with an EO characterized by the highest contents in monoterpene hydrocarbons $(40.9 \pm 5.2 \%)$ and monoterpene alcohols $(39.6 \pm 3.1 \%)$ and the lowest content in sesquiterpene hydrocarbons $(2.5 \pm 0.6 \%)$. S. officinalis forming the Subgroup $C_{1}$ was specified by the highest content in monoterpene ketones; however, it shared with the species of Subgroup $C_{2}$ a relatively high content in sesquiterpene hydrocarbons $(10.0 \pm 3.3 \%)$. $R$. officinalis 1 and $R$. officinalis . $_{2}$ constituting the Subgroup $C_{2}$ were highlighted by the highest mean percentages of monoterpene oxides $(47.2 \pm 0.5$ and $37.6 \pm 0.5 \%)$ respectively and their poverty in the monoterpenic phenols and the sesquiterpenic alcohols. We noted also that $R$. officinalis 2 and $O$. majorana EOs shared together the highest amount of monoterpene hydrocarbons.

\section{Major components}

Twenty components of the essential oils with a minimum content of $3.0 \%$ in at least one species were selected for the PCA and the HCA to evaluate whether they may be useful in reflecting the chemotaxonomic relationships in the four Lamiaceae species (Table 2). The contents of the selected oil components were significantly different between species

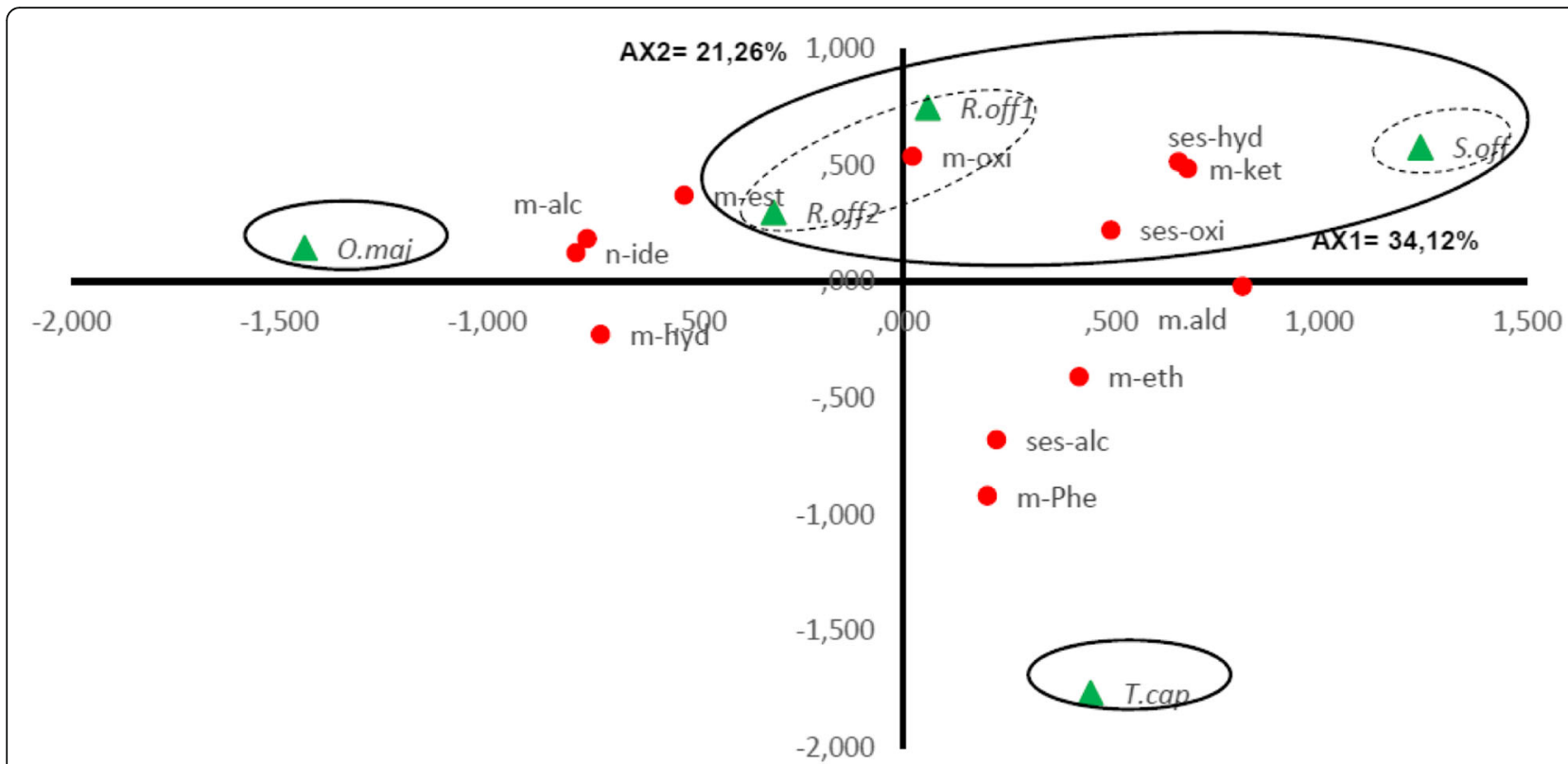

Fig. 2 PCA of chemical classes for S. officinalis, T. capitatus, R. officinalis, $R$. officinalis2 and O. majorana essential oil. m-hyd, Monoterpene hydrocarbons; m-oxi, Monoterpene oxides; m-alc, Monoterpene alcohols; m-ket, Monoterpene Ketones; m-ald, Monoterpene aldehydes; m-est, Monoterpene esters; m-eth, Monoterpene ethers; m-phe, Monoterpene phenols, ses-hyd, Sesquiterpene hydrocarbons; ses-alc, Sesquiterpene alcohols; ses-oxi, Sesquiterpene oxides;n-ide, Not identified. For the Lamiceae species $(\boldsymbol{\Lambda})$ abbreviations see Table 2 


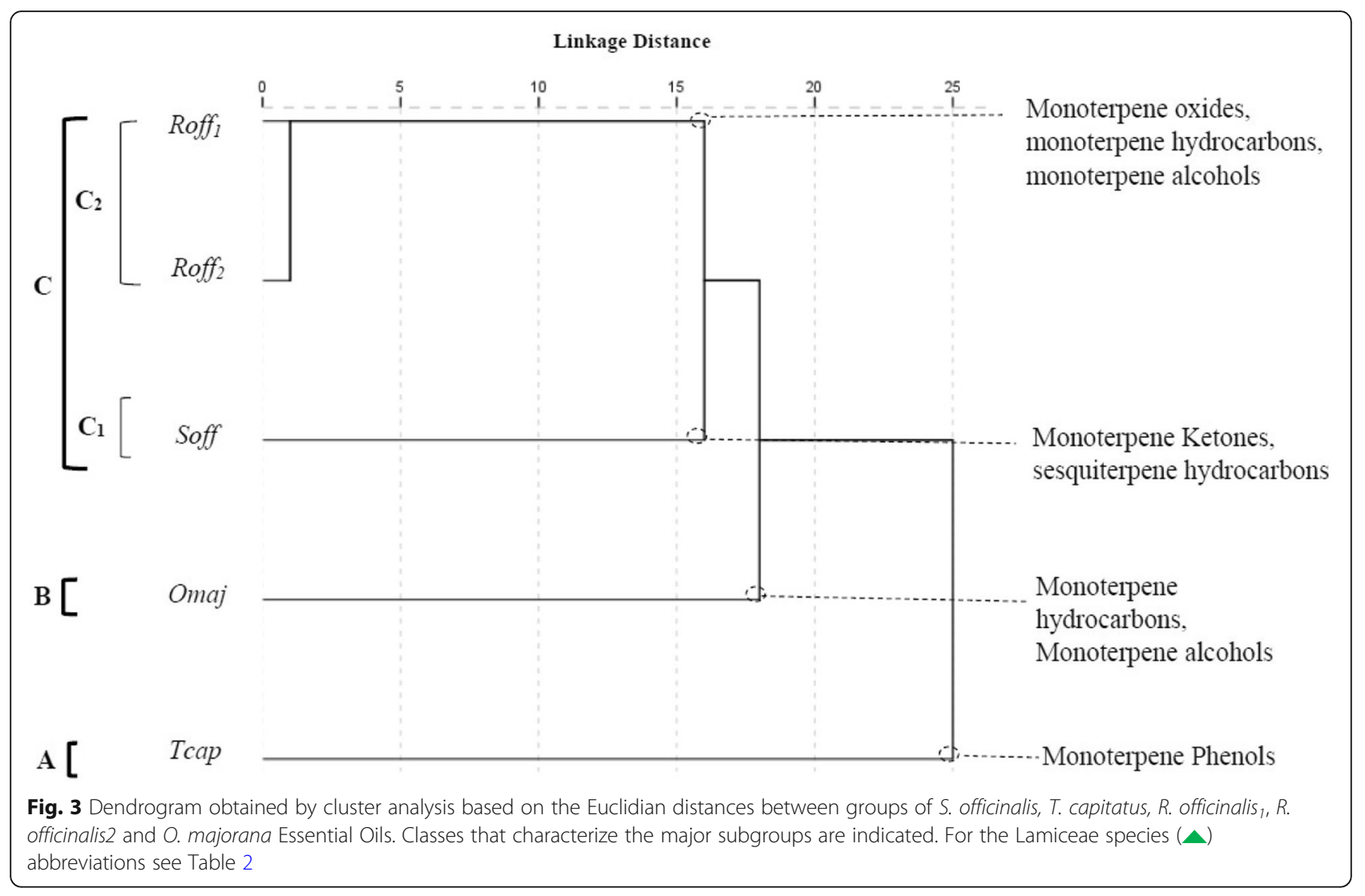

$(p<0.05)$. The PCA horizontal axis explained $56.28 \%$ of the total variance while the vertical axis a further $16.86 \%$ (Fig. 4). The HCA based on the Euclidean distance between groups indicated three species groups $\left(A^{\prime}, B^{\prime}\right.$ and $\left.C^{\prime}\right)$ identified by their essential oil chemotypes with a dissimilarity $>10$ (Fig. 5) which was mainly due to the variation along the major axis in PCA analysis. With a dissimilarity $>5$, group $C^{\prime}$ was divided in two subgroups (C'1 and $C^{\prime} 2$ ) in both HCA and PCA analysis, which was affected essentially by the variation along the vertical axis.

The T. capitatus EO of Group A' stand out forming separate group in both PCA and HCA analysis and was characterized by the highest content of carvacrol (56.1 \pm $3.0 \%)$ and a relatively high contents of $p$-cymene $(7.4 \pm$ $0.8 \%)$ and $\gamma$-terpinene $(10.8 \pm 3.2 \%)$. However, it was very poor in 1,8 -cineole $(2.9 \pm 4.6 \%), \alpha$-pinene $(0.8 \pm$ $0.0 \%)$ and camphene $(0.2 \pm 0.0 \%)$. Group B' correlated positively with axis1 and was represented by $O$. majorana, which $\mathrm{EO}$ was characterized by the highest contents of $\alpha$-terpineol $(27.4 \pm 2.8 \%), \quad \gamma$-terpinene $(16.3 \pm$ $1.5 \%), p$-cymene $(9.7 \pm 0.8 \%), \alpha$-terpinene $(7.7 \pm 1.3 \%)$, and by the lowest content of the compounds which were negatively correlated with axis 1 , such as $\alpha$ - humulene and camphor (tr) .

Subgroup $C^{\prime}{ }_{1}$ was represented by $S$. officinalis, which EO was characterized by the highest contents of $\alpha$ - thujone $(22.8 \pm 1.5 \%), \quad \beta$-thujone $(6.8 \pm 0.5 \%)$ and $\alpha$ humulene $(4.8 \pm 2.0 \%)$.

$R$. officinalis $s_{1}$ and $R$. officinalis ${ }_{2}$ constituted the subgroup $C_{2}{ }_{2}$. Their EOs contained the highest mean percentage in 1,8-cineole ( $47.2 \pm 0.5$ and $37.6 \pm 0.5 \%$, resp.) compared to the moderate level $(10.3 \pm 1.4 \%)$ of this component in S. officinalis. They are characterized by a lower content of camphor $(13.3 \pm 2.9$ and $7.1 \pm 1.3 \%)$ in comparison with $S$. officinalis camphor content (19.3 \pm 2.1\%). The Group C' EOs shared together the presence of the highest mean percentages of $(E)$-caryophyllene $(5.2 \pm 0.9,5.0 \pm 3.1$ and $3.9 \pm 1.3 \%)$ and $\beta$-pinene ( $4.6 \pm$ $1.4,3.6 \pm 0.6$ and $2.6 \pm 0.5 \%$ ) for $R$. officinalis ${ }_{1}, R$. officinalis $_{2}$ and $S$. officinalis EOs respectively. The separation of the two Rosmarinus oil samples was essentially due to the higher content of $\alpha$-pinene in $R$. officinalis 2 EO $(19.4 \pm 5.4 \%)$ versus $(7.0 \pm 3.9 \%)$ for that of $R$. officinalis ${ }_{1}$.

\section{Antibacterial activity}

The essential oils were tested for their supposable antibacterial activity against five model bacteria. Antibacterial effects are reported as inhibition zones, and "in vitro activity" as MIC and MBC. The results obtained using the disc diffusion method recorded in $\mathrm{MH}$ agar were summarized in Table 3. According to the value of the inhibition zone diameter (IZD) expressed in $\mathrm{mm}$, results 
Table 2 Content of S. officinalis, T. capitatus, R. officinalis, R. officinalis2 and O. majorana Essential Oils in the 20 Compounds Selected for the Principal Component and the Hierarchical Cluster Analyses

\begin{tabular}{|c|c|c|c|c|c|c|}
\hline \multirow[t]{2}{*}{ Compound } & \multirow[t]{2}{*}{ Abreviation } & \multicolumn{5}{|l|}{ content [\%] } \\
\hline & & S. officinalis & T. capitatus & R. officinalis, & R. officinalis 2 & O. majorana \\
\hline a-Pinene & $a$-pin & $6.2 \pm 3.0$ & $0.8 \pm 0.0$ & $7.0 \pm 3.9$ & $19.4 \pm 5.4$ & $1.1 \pm 0.3$ \\
\hline Camphene & Camp & $6.2 \pm 1.4$ & $0.2 \pm 0.0$ & $2.7 \pm 1.4$ & $6.5 \pm 1.6$ & $0.2 \pm 0.0$ \\
\hline Sabinene & Sab & $0.1 \pm 0.0$ & a) & $0.1 \pm 0.0$ & $T^{b)}$ & $2.2 \pm 0.5$ \\
\hline$\beta$-Pinene & $\beta$-pin & $2.6 \pm 0.5$ & $0.5 \pm 0.1$ & $4.6 \pm 1.4$ & $3.6 \pm 0.6$ & $0.6 \pm 0.1$ \\
\hline$a$-Terpinene & a-terp & $0.1 \pm 0.2$ & $2.2 \pm 0.5$ & $0.1 \pm 0.1$ & $0.4 \pm 0.2$ & $7.7 \pm 1.3$ \\
\hline p-Cymene & p-cym & $2.1 \pm 0.2$ & $7.4 \pm 0.8$ & $1.9 \pm 0.1$ & $0.9 \pm 1.0$ & $9.7 \pm 0.8$ \\
\hline Limonene & $\operatorname{Lim}$ & $1.6 \pm 0.4$ & $0.5 \pm 0.4$ & - & $2.5 \pm 0.3$ & - \\
\hline 1,8-Cineole & $1,8-\operatorname{cin}$ & $10.3 \pm 1.4$ & $2.9 \pm 4.6$ & $47.2 \pm 0.5$ & $37.6 \pm 0.5$ & $4.0 \pm 0.5$ \\
\hline$\gamma$-Terpinene & $\gamma$-terp & $0.6 \pm 0.0$ & $10.8 \pm 3.2$ & $0.3 \pm 0.0$ & $0.5 \pm 0.1$ & $16.3 \pm 1.5$ \\
\hline (E)-Sabinene hydrate & E-sab hydr & - & $1.1 \pm 1.0$ & - & - & $3.7 \pm 0.2$ \\
\hline Linalool & $\operatorname{Lin}$ & - & $0.5 \pm 0.9$ & $1.0 \pm 0.3$ & $0.5 \pm 0.1$ & $2.8 \pm 0.5$ \\
\hline$a$-Thujone & $a$-thuj & $22.8 \pm 1.5$ & - & $\operatorname{Tr}$ & $0.1 \pm 0.0$ & - \\
\hline$\beta$-Thujone & $\beta$-thuj & $6.8 \pm 0.5$ & - & $0.1 \pm 0.0$ & $\operatorname{Tr}$ & - \\
\hline Camphor & Camph & $19.3 \pm 2.1$ & $1.6 \pm 2.7$ & $13.3 \pm 2.9$ & $7.1 \pm 1.3$ & $\operatorname{Tr}$ \\
\hline Borneol & Born & $4.0 \pm 0.4$ & $1.0 \pm 0.8$ & $5.4 \pm 1.5$ & $4.4 \pm 1.2$ & - \\
\hline$a$-Terpineol & a-terpi & $0.1 \pm 0.0$ & $0.2 \pm 0.4$ & $2.6 \pm 0.7$ & $1.6 \pm 0.6$ & $27.4 \pm 2.8$ \\
\hline Verbenone & Verb & - & - & $\operatorname{Tr}$ & $\operatorname{Tr}$ & $3.7 \pm 0.5$ \\
\hline Carvacrol & Carv & $\operatorname{Tr}$ & $56.1 \pm 3.0$ & - & - & $0.6 \pm 0.4$ \\
\hline (E)-Caryophyllene & (E)-cary & $3.9 \pm 1.3$ & $4.2 \pm 0.3$ & $5.2 \pm 0.9$ & $5.0 \pm 3.1$ & $1.7 \pm 0.5$ \\
\hline$a$-Humulene & a-hum & $4.8 \pm 2.0$ & $0.2 \pm 0.0$ & $0.3 \pm 0.4$ & $0.7 \pm 0.4$ & $0.1 \pm 0.0$ \\
\hline
\end{tabular}

${ }^{a}$-: not detected. ${ }^{b} \operatorname{Tr} \operatorname{Trace}(<0.1 \%)$

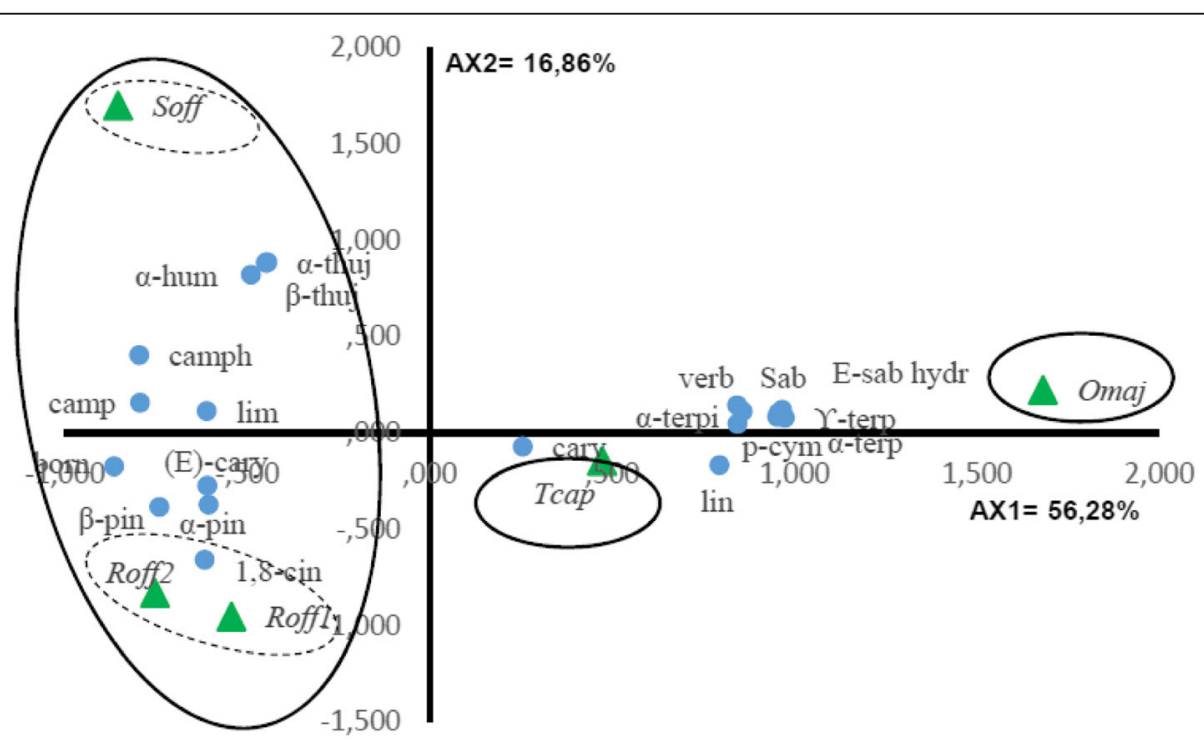

Fig. 4 PCA of the 20 major components of S. officinalis, T. capitatus, R. officinalis, $R$. officinalis, and O. majorana essential oils. For the Lamiceae species ( $\mathbf{\Lambda}$ ) and components (o) abbreviations see Table 2 


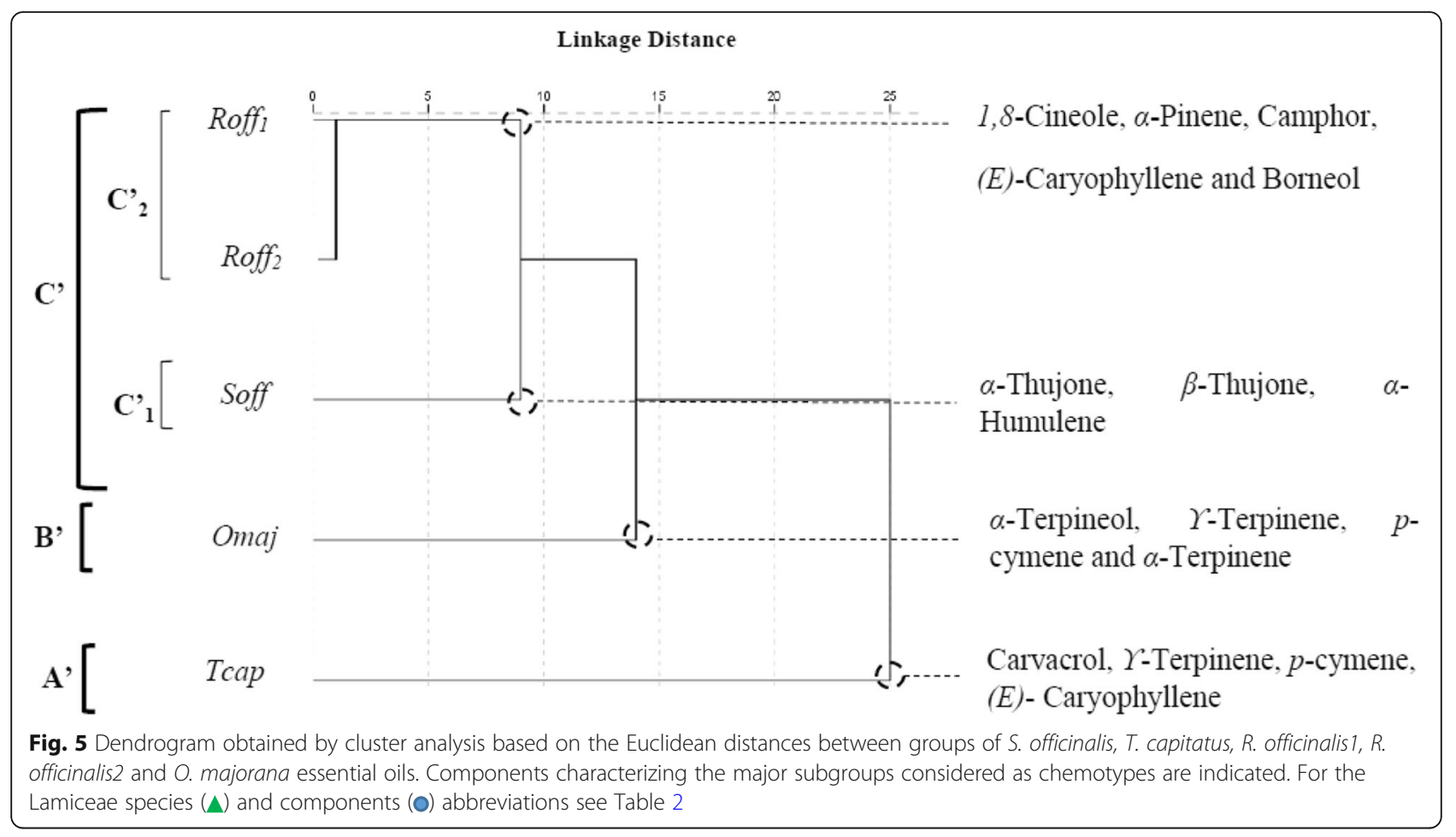

were appreciated as follows: not sensitive (-) for diameter equal to $8 \mathrm{~mm}$ or below; sensitive $(+)$ for diameter between 8 and $14 \mathrm{~mm}$; very sensitive $(++)$ for diameter 14 and $20 \mathrm{~mm}$ and extremely sensitive $(+++)$ for diameter equal or larger than $20 \mathrm{~mm}[34,35]$.

To determine the antibacterial power of the studied $\mathrm{EOs}$, the MBC/MIC ratio was calculated and interpreted based on the classification of Schwarz et al. (2010). The EO is considered bactericidal when this ratio is lower or equal to 4 whereas it's bacteriostatic when it's greater than 4 [36].

To evaluate the correlations between the antibacterial activities and the essential oils, all the mean values of the inhibition zone diameters were subjected to PCA and HCA analysis.
The PCA horizontal axis explained $73.18 \%$ of the total variance while the vertical axis a further 16.43\% (Fig. 6). The HCA based on the Euclidean distances between groups indicated 3 groups (A", B" and C") of species identified by their antibacterial inhibition growth with a dissimilarity $\geqslant 10$. The first principal axis separated the groups $\mathrm{A}^{\prime \prime}$ and $\mathrm{C}^{\prime \prime}$, whereas the second principal axis allowed the separation of the group $B$ " from the groups $\mathrm{C}^{\prime \prime}$ in the ACP (Fig. 6) and the HCA (Fig. 7).

Group A" was constituted by the standard antibiotic Gentamicin ${ }^{\circ}$ and $T$. capitatus, which were characterized by being very active or extremely active against all the tested strains $(15.0 \pm 1.0<\mathrm{IZD}<30.0 \pm 1.0 \mathrm{~mm})$. With a dissimilarity $>5$, group A" was divided in two subgroups $\left(\mathrm{A}^{\prime \prime}{ }_{1}\right.$ and $\left.\mathrm{A}^{\prime \prime}{ }_{2}\right)$. B. subtilis was extremely sensitive to

Table 3 Antibacterial activity (Diameter of the inhibition zone) of the 5 Tunisian Lamaiaceae plants essential oils and antibiotic *)

\begin{tabular}{|c|c|c|c|c|c|}
\hline \multirow[t]{2}{*}{ Essential oils } & \multicolumn{5}{|c|}{ Microorganisms } \\
\hline & $\begin{array}{l}\text { E. coli } \\
\text { Ecol }\end{array}$ & $\begin{array}{l}\text { S. enterica } \\
\text { Sent }\end{array}$ & $\begin{array}{l}\text { P. aeruginosa } \\
\text { Paer }\end{array}$ & $\begin{array}{l}\text { B. subtilis } \\
\text { Bsub }\end{array}$ & $\begin{array}{l}\text { S. aureus } \\
\text { Saur }\end{array}$ \\
\hline S. officinalis & $11.3^{\mathrm{a}} \pm 1.2$ & $7.7^{\mathrm{a}} \pm 1.2$ & $7.0^{\mathrm{a}} \pm 1.0$ & $17.3^{b} \pm 0.6$ & $8.3^{a} \pm 0.6$ \\
\hline T. capitatus & $20.3^{d} \pm 0.6$ & $20.0^{d} \pm 1.0$ & $20.3^{d} \pm 0.6$ & $30.0^{e} \pm 1.0$ & $15.0^{c} \pm 1.0$ \\
\hline R. officinalis, & $11.0^{\mathrm{a}} \pm 1.0$ & $8.7^{a} \pm 0.6$ & $8.3^{b} \pm 0.8$ & $19.3^{c} \pm 1.2$ & $10.0^{\mathrm{ab}} \pm 1.7$ \\
\hline R. officinalis 2 & $15.3^{\mathrm{b}} \pm 0.6$ & $7.7^{\mathrm{a}} \pm 1.2$ & $6.0^{a} \pm 0.0$ & $25.3^{d} \pm 0.6$ & $10.3^{\mathrm{ab}} \pm 0.6$ \\
\hline O. majorana & $14.0^{b} \pm 1.0$ & $14.0^{b} \pm 1.0$ & $6.3^{a} \pm 0.6$ & $6.0^{a} \pm 0.0$ & $12.0^{b} \pm 1.0$ \\
\hline Gentamicine $^{\circledast}$ & $17.3^{c} \pm 0.6$ & $17.3^{c} \pm 0.6$ & $16.0^{\complement} \pm 1.0$ & $24.3^{d} \pm 1.2$ & $21.7^{d} \pm 1.5$ \\
\hline
\end{tabular}

*Values are means $(\mathrm{mm} . \pm \mathrm{SD})$ of the triplicate determination

*Values with different letters differ significantly by SNK test $(p<0.05)$ 


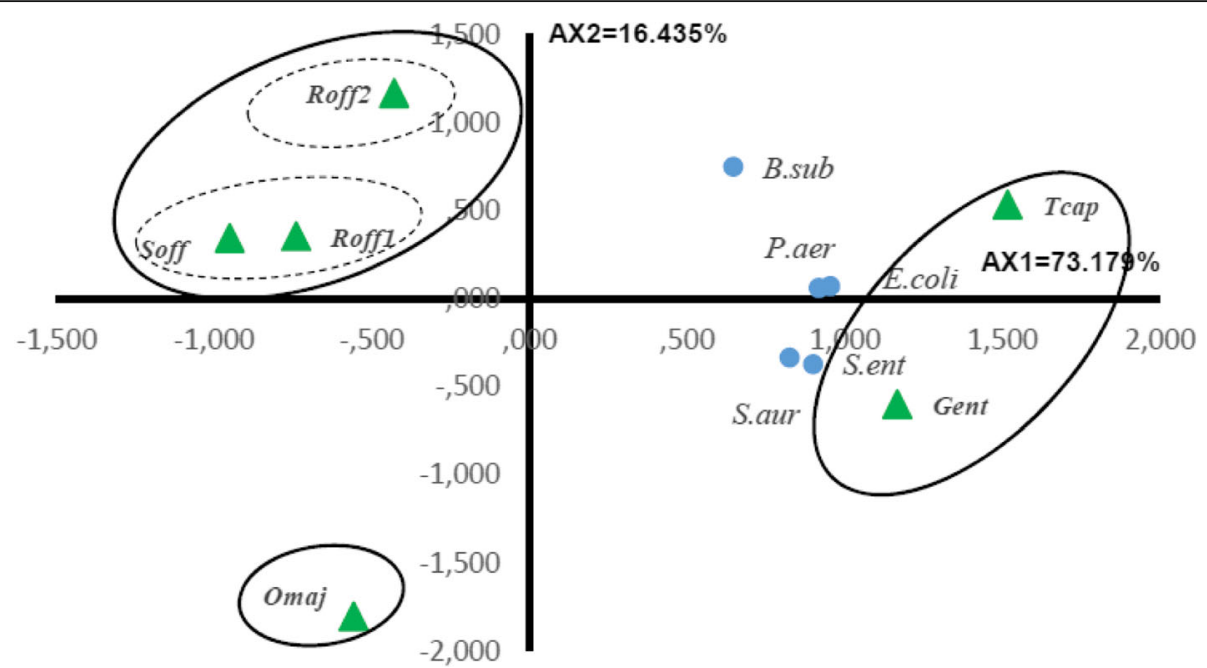

Fig. 6 PCA of the antibacterial activity of S. officinalis, T. capitatus, R. officinalis, R. officinalis, and O. majorana essential oils against five bacterial strains. For the Lamiceae species ( $\mathbf{A}$ ) abbreviations see Table 2. For the bacterial strains (0) abbreviations see Table 3

both $T$. capitatus and Gentamicine forming respectively Subgroup $A^{\prime \prime}{ }_{1}$ and Subgroup $A^{\prime \prime}{ }_{2}$. T. capitatus was characterized by being extremely active against $E$. coli $(20.3 \pm 0.6 \mathrm{~mm})$, S. enterica $(20.0 \pm 1.0 \mathrm{~mm})$ and P. aeruginosa $(20.3 \pm 0.6 \mathrm{~mm})$ and very active against $S$. aureus $(15.0 \pm 1.0 \mathrm{~mm})$ while Gentamicine ${ }^{\bullet}$ was extremely active against this last strain and very active against the three first ones.

Group B" was constituted by O. majorana, it stands out forming a separate group in HCA and PCA and correlated negatively with the two principle axis, it was characterized by being inactive against $B$. subtilis $(6.0 \pm 0.0 \mathrm{~mm})$ and moderately active against $E$. coli, $S$. enterica and $S$. aureus $(14.0 \pm 1.0,14.0 \pm 1.0,12.0 \pm 10 \mathrm{~mm}$, respectively).

Group C" was divided in two Subgroups $C^{\prime \prime}{ }_{1}$ represented by $R$. officinalis 1 and S. officinalis, and Subgroup $C^{\prime \prime}{ }_{2}$ represented by $R$. officinalis $2_{2}$. Group $C^{\prime \prime}$ species were characterized by being inactive or moderately active against $S$. enterica $(7.7 \pm 1.2,8.7 \pm 0.6,7.7 \pm 1.2 \mathrm{~mm})$ and $P$. aeruginosa $(7.0 \pm 1.0,8.3 \pm 0.8,6.0 \pm 0.0 \mathrm{~mm})$, but

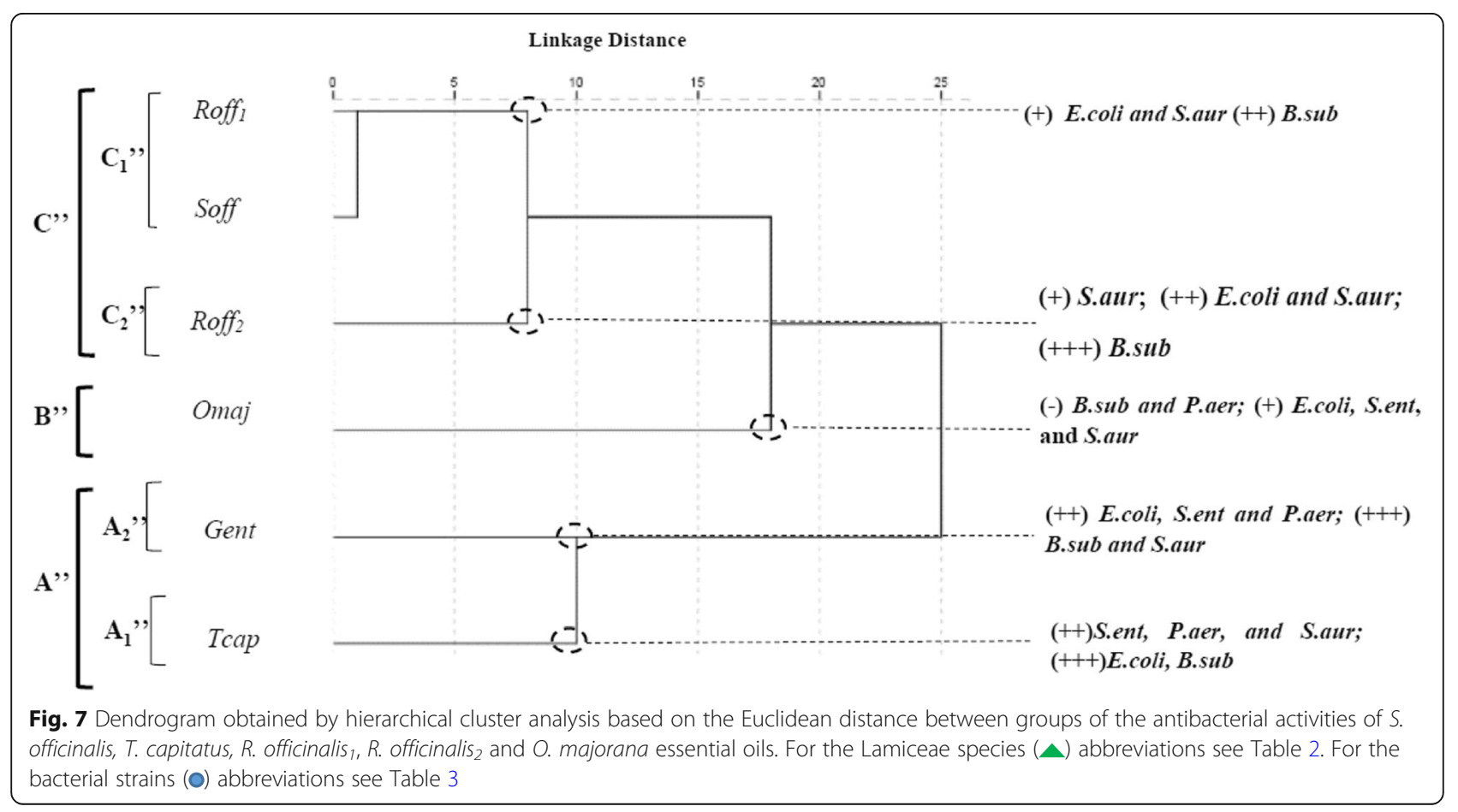


active against $S$. aureus $(8.3 \pm 0.6,10.0 \pm 1.7,10.3 \pm 0.6$ $\mathrm{mm})$. Subgroup $C^{\prime \prime}{ }_{2}$ represented by $R$. officinalis ${ }_{2}$ oil was characterized by being extremely active against $B$. subtilis $(25.3 \pm 0.6 \mathrm{~mm})$ and very active against $E$. coli $(15.3 \pm$ $0.6 \mathrm{~mm}$ ) in comparison with Subgroup $C^{\prime \prime}{ }_{1}$ species $(17.3 \pm 0.6-19.3 \pm 1.2 \mathrm{~mm} ; \quad 11.0 \pm 1.0-11.3 \pm 1.2 \mathrm{~mm}$; resp.).

\section{Besides,}

Table 4 summarizes the MIC and MBC values of the tested Lamiaceae EOs obtained by the dilution method in $\mathrm{MH}$ broth. T. capitatus showed the most important bactericidal effect against all the strains (MIC range: $0.73-2.94 \mathrm{mg} \mathrm{mL}^{-1}$; $\mathrm{MBC}$ range: $0.73-2.94 \mathrm{mg} \mathrm{mL}^{-1}$ ) while $R$. officinalis $s_{2}$ exhibited the weaker antibacterial activity against the tested strains (MIC range: 45.50-91.00 $\mathrm{mg} \mathrm{mL}{ }^{-1}$; $\mathrm{MBC}$ range: $91.00-182.00 \mathrm{mg} \mathrm{mL}^{-1}$ ).

\section{Discussion}

\section{Chemical composition}

Tunisian S. officinalis EO have nearly similar composition to that obtained by Gomes et al. (2001) and

Table 4 Minimal inhibition concentration (MIC), minimal bactericidal concentration $(\mathrm{MBC}$ ) and ration $\mathrm{MBC} / \mathrm{MIC}$ of the aerial parts essential oils extracted from 05 Tunisian Lamiaceae plants against 5 bacterial strains

\begin{tabular}{|c|c|c|c|c|c|}
\hline \multirow[t]{2}{*}{ Essential oils } & \multicolumn{3}{|c|}{ Tested microorganisms } & \multirow[b]{2}{*}{ B. sub } & \multirow[b]{2}{*}{ S. aur } \\
\hline & $\overline{E .\left(c^{\prime} / i^{a)}\right.}$ & S. ent & P. aer & & \\
\hline \multicolumn{6}{|l|}{ S. officinalis } \\
\hline MIC & $22.78^{\mathrm{b})}$ & 22.78 & 22.78 & 22.78 & 22.78 \\
\hline $\mathrm{MBC}$ & 45.55 & 22.78 & 22.78 & 22.78 & 22.78 \\
\hline $\mathrm{MBC} / \mathrm{MIC}$ & 2.00 & 1.00 & 1.00 & 1.00 & 1.00 \\
\hline \multicolumn{6}{|l|}{ T. capitatus } \\
\hline MIC & 0.73 & 0.73 & 1.47 & 2.94 & 0.73 \\
\hline$M B C$ & 0.73 & 0.73 & 2.94 & 2.94 & 0.73 \\
\hline $\mathrm{MBC} / \mathrm{MIC}$ & 1.00 & 1.00 & 2.00 & 1.00 & 1.00 \\
\hline \multicolumn{6}{|l|}{ R. officinalis, } \\
\hline MIC & 11.38 & 22.75 & 22.75 & 22.75 & 22.75 \\
\hline $\mathrm{MBC}$ & 22.75 & 22.75 & 45.50 & 22.75 & 45.50 \\
\hline $\mathrm{MBC} / \mathrm{MIC}$ & 2.00 & 1.00 & 2.00 & 1.00 & 2.00 \\
\hline \multicolumn{6}{|l|}{ R. officinalis } \\
\hline MIC & 45.50 & 45.50 & 91.00 & 91.00 & 45.50 \\
\hline $\mathrm{MBC}$ & 182.00 & 91.00 & 182.00 & 91.00 & 91.00 \\
\hline $\mathrm{MBC} / \mathrm{MIC}$ & 4.00 & 2.00 & 2.00 & 1.00 & 2.00 \\
\hline \multicolumn{6}{|l|}{ O. majorana } \\
\hline MIC & 45.00 & 22.50 & 45.00 & 22.50 & 22.50 \\
\hline$M B C$ & 45.00 & 22.50 & 45.00 & 22.50 & 22.50 \\
\hline $\mathrm{MBC} / \mathrm{MIC}$ & 1.00 & 1.00 & 1.00 & 1.00 & 1.00 \\
\hline
\end{tabular}

${ }^{\mathrm{a}}$ E. coli = Escherichia coli CIP 53.126; S. ent = Salmonella enterica CIP80.39; P. aer = Pseudomonas aeruginosa CIP 82118; B. sub=Bacillus subtilis CIP 52.62; S. aur = Staphylococcus aureus CIP 4.83.

${ }^{b}$ Values are expressed as $\mathrm{mg} / \mathrm{mL}$
Bouaziz et al. (2009) [37, 38] and disagree with Hayouni et al. (2008) who reported that 1,8-cineole (33.27\%) was the major compound followed by $\beta$-thujone (18.40\%), $\alpha$-thujone (13.45\%), borneol (7.37\%) and camphor (3.31\%) [13].

T. capitatus investigated EO was characterized by a higher amount in monoterpene hydrocarbons than that noted by Russo et al. (2013) [39] and Jemaa et al. (2018) [40] (9.56-13.15\%), and (15.10\%) respectively. Their EOs were richer in carvacrol (76.79 and 76.1\%; resp.) but poor in $\gamma$-terpinene (3.71 and 6.7\%; resp.) in comparison with our finding. El Jalel et al. (2018) found that the main constituents of $T$. capitatus aerial part EO from Libya were carvacrol (58.56\%), which was comparable to our finding, while $\beta$-caryophyllene (7.41\%), ledene (6.57\%), caryophyllene oxide $(6.26 \%)$ and $\alpha$-humulene $(5.20 \%)$ contents were higher than that obtained in our results [41]. We noticed the presence of a relatively high content of 1,8-cineole (2.9\%) in comparison with the cited studies.

O. majorana EO content in monoterpene hydrocarbons (40.9\%) and oxygenated monoterpenes (51.5\%) was comparable to the results of Hajlaoui et al. (2016) [22] while El Akhal et al. (2014) showed a higher content in monoterpene hydrocarbons $(51.7 \%)$ and a lower content in oxygenated monoterpene (44.38\%) [42]. Moreover, Hajlaoui et al. (2016) and Mossa et al. (2011) characterized different major compound such as terpinene-4-ol (23.2, 29.97\%; resp.) [21] [22]. However, $\boldsymbol{Y}$-terpinene was the second most important component with relatively comparable amounts (15.4, 18.57 and 10.5\%).

Results obtained for $R$. officinalis EOs were in accordance with previous studies reporting that 1,8-cineole (37.6 and 47.2\%), camphor (7.1 and 13.3\%) and $\alpha$-pinene (7.0 and 19.4\%) were the major components of $R$. officinalis EO [43, 44] while Verbenone (4.4-24.9\%) was found to be the major component of $R$. officinalis EO from Corsica and Sardinia [45].

\section{Antibacterial activity}

The essential oils antibacterial activity showed considerable variation among the different Lamiaceae species and bacterial strains. T. capitatus EO antibacterial activity was even higher than that of the standard antibiotic Gentamicine $^{\circ}$. The IZD of $T$. capitatus ranged from $(15.0 \pm 1.0$ to $30.0 \pm 1.0 \mathrm{~mm})$ and MIC ranged from (0.73 to $2.94 \mathrm{mg} / \mathrm{mL}$ ). In fact, $T$. capitatus $\mathrm{EO}$ was characterized by the most important mean percentage of the monoterpenoid phenol carvacrol $(56.1 \pm 3.0 \%)$, and important contents of hydrocarbon monoterpenes $p$-cymene $(7.4 \pm 0.8 \%)$ and $\gamma$-terpinene $(10.8 \pm 3.2 \%)$. Previous study proved that the thyme essential oil activity was mainly due to the presence of phenolic compounds and monoterpene hydrocarbons [46]. It was reported that an 
antimicrobial action of phenolic compounds was related to the inactivation of certain cellular enzymes. It depends on membrane permeability changes and consequently on the rate of penetration into the cell [39]. Increased membrane permeability is a major factor in the mechanism of antimicrobial action of phenolic compounds, which may disrupt membranes and cause a loss of cellular integrity and eventual cell death.

Activity amongst the phenols and alcohols is at least partly due to the hydroxyl group, which has intrinsic antimicrobial activity and contributes to the relatively greater solubility of these components in biological membranes. Furthermore, the ability of components to release or accept protons has been postulated as an important factor in antimicrobial activity [5, 47, 48].

Another study attributed the activity of carvacrol to its hydroxyl group. In fact, they confirmed the importance of this group in term of activity in the phenolic structure when they compared carvacrol to its methyl ether [49] it was demonstrated in the same study that $p$-Cymene, the third major element according to percentage, does not show antibacterial efficacy when used alone. Moreover, other studies [50, 51] have shown that EOs exhibit stronger antimicrobial activity than that of their major constituents or their mixtures which suggests synergistic effects of the minor components, but also the importance of all components in relation to the biological activity of EOs.

The activity was decreased with $O$. majorana oil with MIC values ranging from 22.5 to $45.0 \mathrm{mg} / \mathrm{mL}$. This EO contained a very lower content of carvacrol and higher mean percentage of $\mathrm{p}$-cymene and $r$-terpinene. $O$. majorana oil was also characterized by the highest amount of monoterpene hydrocarbons, and alcohol monoterpene $\alpha$-terpineol. The combination of these results permitted as to deduce that the main antibacterial activity against the studied strains might be attributed to the richness of the essential oils in the phenol carvacrol.

It is interesting to note the susceptibility to the $T$. capitatus EO of $P$. aeruginosa, which is known to be a very resistant bacterium even to synthetic drugs, with MICs ranging from 0.73 to $2.94 \mathrm{mg} / \mathrm{mL}$. This result confirm those found with EL Jalel et al. (2018) [41].

$S$. officinalis, $R$. officinalis ${ }_{1}$ and $R$. officinalis $s_{2}$ were placed in the same group in both antibacterial ACP and HCA analyses, but within chemical ACP and HCA analysis, they were classified in two different subgroups. $S$. officinalis was characterized by the most important amount in monoterpene ketones $(48,9 \pm 4.1 \%)$ while $R$. officinalis were characterized by the highest amounts of monoterpenes oxides $(47.2 \pm 0.5$ and $37.6 \pm 0.5 \%)$.

These results suggested that the major components from these two chemical classes could be responsible for producing a similar inhibition. Our results were confirmed by Hammer et al. who demonstrated that camphor and 1 , 8 -cineole were the principle components responsible for the antibacterial activity against B. subtilis, E. coli and $S$. aureus [5]. In the same way, Longaray Delamare et al. (2007) attributed the antimicrobial activities of S. officinalis against $E$. coli, $P$. aeruginosa, $B$. subtilis and $S$. aureus to the presence of high concentrations of thujone, 1,8-cineole and camphor [17].

The $R$. officinalis EOs was noted to be active against all the bacterial strains but in different degrees. In fact, $R$. officinalis ${ }_{1}$ was more potent with MICs values ranging from $11.38 \mathrm{mg} / \mathrm{mL}$ to $22.75 \mathrm{mg} / \mathrm{mL}$ when $R$. officinalis ${ }_{2}$ MICs ranged from $45.00 \mathrm{mg} / \mathrm{mL}$ to $91.00 \mathrm{mg} / \mathrm{mL}$. These results could be explained by the difference in the mean percentages of some components in these EOs. Actually, R. officinalis ${ }_{1} \mathrm{EO}$ was richer in oxygenated monoterpene active compounds such as 1,8 - cineole $(47.2 \pm 0.5 \%$ Vs. $37.6 \pm 0.5 \%)$ and camphor $(13.3 \pm 2.9 \%$ Vs. $7.1 \pm 1.3 \%)$. However, $R$. officinalis ${ }_{2}$, was characterized by higher amounts of hydrogenated monoterpene compounds, like $\alpha$ - pinene $(19.4 \pm 5.4 \%$ Vs. $7.0 \pm 5.4 \%)$ and camphene (6.5 $\pm 1.6 \%$ Vs. $2.7 \pm 1.4 \%)$. These finding confirm the results of Griffin et al. (1999) and Van de Vel et al. (2017). These authors suggested that the water solubility and the hydrogen bonding capacity are the main factors influencing MIC values of terpenoids against $P$. aeruginosa, S. aureus, and E. coli [52, 53], since 1,8-cineole and camphor are distinguished by a higher water solubility and hydrogen bonding capacity than $\alpha$ - pinene and camphene. Thereby, we can confirm that the qualitative and quantitative differences between $R$. officinalis EOs chemical composition could affect their antibacterial activity [54].

The $\mathrm{MBC} / \mathrm{MIC}$ ratio ranged from 1 to 4 for all the EOs, indicating a bactericidal activity for these lamiaceae EOs against the tested bacterial strains. Other Moroccan studies showed that $R$. officinalis had a bacteriostatic effect on S. aureus [44], whereas O. majorana had a bactericidal effect on $E$. coli and was bacteriostatic on $S$. aureus and B. subtilis [55]. The variation in the EOs antibacterial activity could be attributed to the variation of the chemical composition, which is depending of some factors including species, the plant origin, climatic conditions, distillation conditions, adaptive metabolism of plant $[56,57]$ as well as to the bacterial strains susceptibility [58].

\section{Conclusion}

The PCA and the HCA of the chemical composition of the studied Lamiaceae EOs separated them in four groups and sub-groups with different chemotypes. $T$. capitatus was the richest species in carvacrol, S. officinalis was the richest species in $\alpha$-thujone, and $R$. officina$l_{i s_{1}}$ was the richest species in 1,8-cineole. The EOs 
antibacterial activity varied significantly within species and within strains. In general, EOs have shown promising antibacterial activities we noted a pronounced activity of $T$. capitatus against $P$. aeruginosa. These results may represent useful and valuable leads for the development of new disinfectant products.

\section{Abbreviations}

R. officinalis: Rosmarinus officinalis; T. capitatus: Thymus capitatus; $O$. majorana: Origanum majorana; S. officinalis: Salvia officinalis; GC: Gaz chromatography; GC/MS: Gaz chromatography coupled to the mass spectroscopy; HP: Hewlett-Packard; FID: Flame ionization detector; $\mathrm{MH}$ : Mueller-Hinton; MIC: Minimal inhibition concentration;

MBC: Minimum bactericidal concentration; IZD: Inhibition zone diameter; DMSO: Dimethyl sulfoxide; PCA: Principal components analysis; HCA: Hierarchical clusters analysis; RI: Retention index; Gram(-): Gram negative; Gram(+): Gram positive

\section{Authors' contributions}

SM designed the study, carried experimental work, performed the data analyses, carried out the statistical analysis and wrote the manuscript. AE supervised the research and experimental work, involved in the data analysis and the interpretation of the results, and revised the manuscript. AT involved in the data analysis and the interpretation of results. AM involved in the interpretation of antibacterial activities results. IC helped in the GC-MS analyses. BJ helped in the experimental procedures of the antibacterial activities. R.C and SF supervised the research and experimental work. The authors read and approved the final manuscript.

\section{Funding}

This research was supported by the "Ministère Tunisien de l'Enseignement Supérieur, de la Recherche Scientifique et de la Technologie" through the " Laboratoire de Développement chimique, galénique et pharmacologique des médicaments " (LR12ES09), and "Laboratoire des Maladies Transmissibles et Substances biologiquement actives" (LR99ES27).

\section{Availability of data and materials}

Data and materials are available from authors on reasonable request.

\section{Ethics approval and consent to participate}

Not applicable.

\section{Consent for publication}

Not applicable.

\section{Competing interests}

The authors declare that they have no competing interests.

\footnotetext{
Author details

'Laboratory of Chemical, Pharmaceutical and Pharmacological Drug Development LR12ES09, Faculty of Pharmacy, University of Monastir, rue Avicenne, 5000 Monastir, Tunisia. ${ }^{2}$ Laboratory of Pharmacognosy, Faculty of Pharmacy, University of Monastir, Avenue Avicenne, 5000 Monastir, Tunisia. ${ }^{3}$ Laboratory of Antimicrobial Resistance LR99ES09, Faculty of Medicine of Tunis, University of Tunis El Manar, Tunis, Tunisia. ${ }^{4}$ Department of Biochemistry, Faculty of Medicine, University of Monastir, Rue Avicenne, 5000 Monastir, Tunisia. ${ }^{5}$ Laboratory of Transmissible Diseases and Biologically Active Substances LR99ES27, Faculty of Pharmacy, University of Monastir, rue Avicenne, 5000 Monastir, Tunisia. ${ }^{6}$ Biochemistry Laboratory CHU Farhat Hached, 4000 Sousse, Tunisia.
}

\section{Received: 28 August 2019 Accepted: 9 March 2020}

Published online: 03 April 2020

\section{References}

1. Cermelli C, Fabio A, Fabio G, Quaglio P. Effect of eucalyptus essential oil on respiratory bacteria and viruses. Curr Microbiol. 2008;56(1):89-92.
2. Pye CR, Bertin MJ, Lokey RS, Gerwick WH, Linington RG. Retrospective analysis of natural products provides insights for future discovery trends. Proc Natl Acad Sci. 2017;114(22):5601-6.

3. Dixon RA. Natural products and plant disease resistance. Nature. 2001; 411(6839):843-7.

4. Patridge $E$, Gareiss P, Kinch MS, Hoyer D. An analysis of FDA-approved drugs: natural products and their derivatives. Drug Discov Today. 2016;21(2): 204-7.

5. Hammer KA, Carson CF. Antibacterial and antifungal activities of essential oils. In: Thormar $\mathrm{H}$, editor. Lipids and essential oils as antimicrobial agents. Chichester: Wiley; 2010. p. 255-306.

6. Militello M, Settanni L, Aleo A, Mammina C, Moschetti G, Giammanco GM, et al. Chemical composition and antibacterial potential of Artemisia arborescens L. Essential Oil Curr Microbiol. 2011;62(4):1274-81.

7. Schuenzel KM, Harrison MA. Microbial antagonists of foodborne pathogens on fresh, minimally processed vegetables. J Food Prot. 2002;65(12):1909-15.

8. Tepe B, Daferera D, Sökmen M, Polissiou M, Sökmen A. In vitro antimicrobial and antioxidant activities of the essential oils and various extracts of Thymus eigii M. Zohary et P.H. Davis. J Agric Food Chem. 2004;52(5):1132-7.

9. Sim LY, Abd Rani NZ, Husain K. Lamiaceae: an insight on their anti-allergic potential and its mechanisms of action. Front Pharmacol. 2019;10:677.

10. Barros L, Heleno SA, Carvalho AM, Ferreira ICFR. Lamiaceae often used in Portuguese folk medicine as a source of powerful antioxidants: vitamins and phenolics. LWT Food Sci Technol. 2010;43(3):544-50.

11. Mulas M. Traditional uses of LABIATAE in the MEDITERRANEAN AREA. Acta Hortic. 2006;723:25-32

12. Kandil O, Radwan NM, Hassan AB, Amer AMM, El-Banna HA, Amer WMM. Extracts and fractions of Thymus capitatus exhibit antimicrobial activities. J Ethnopharmacol. 1994;44(1):19-24.

13. Hayouni EA, Chraief I, Abedrabba M, Bouix M, Leveau J-Y, Mohammed $H$, et al. Tunisian Salvia officinalis L. and Schinus molle L. essential oils: their chemical compositions and their preservative effects against salmonella inoculated in minced beef meat. Int J Food Microbiol. 2008;125(3):242-51.

14. Khedher MRB, Khedher SB, Chaieb I, Tounsi S, Hammami M. Chemical composition and biological activities of Salvia officinalis essential oil from Tunisia. EXCLI J. 2017;16:160-73.

15. Loizzo MR, Saab AM, Tundis R, Statti GA, Menichini F, Lampronti I, et al. Phytochemical analysis andin vitro antiviral activities of the essential oils of seven Lebanon species. Chem Biodivers. 2008:5(3):461-70.

16. Fellah S, Diouf PN, Petrissans M, Perrin D, Romdhane M, Abderrabba M. Chemical composition and antioxidant properties of Salvia officinalis L. oil from two culture sites in Tunisia. J Essent Oil Res. 2006;18(5):553-6.

17. Longaray Delamare AP, Moschen-Pistorello IT, Artico L, Atti-Serafini L, Echeverrigaray S. Antibacterial activity of the essential oils of Salvia officinalis L. and Salvia triloba L. cultivated in South Brazil. Food Chem. 2007;100(2): 603-8.

18. Ribeiro-Santos R, Carvalho-Costa D, Cavaleiro C, Costa HS, Albuquerque TG, Castilho MC, et al. A novel insight on an ancient aromatic plant: the rosemary (Rosmarinus officinalis L.). Trends Food Sci Technol. 2015;45(2): 355-68.

19. Sasikumar B. Handbook of herbs and spices, Woodhead publishing series in food science, technology and nutrition, vol. 1. 2nd ed; 2012. p. 452-68.

20. Achour M, Mateos R, Ben Fredj M, Mtiraoui A, Bravo L, Saguem S. A comprehensive characterisation of rosemary tea obtained from Rosmarinus officinalis L. collected in a sub-humid Area of Tunisia: compounds from Rosmarinus officinalis tea. Phytochem Anal. 2018;29(1):87-100.

21. Mossa ATH, Nawwar G. Free radical scavenging and antiacetylcholinesterase activities of Origanum majorana L. essential oil. Hum Exp Toxicol. 2011; 30(10):1501-13.

22. Hajlaoui H, Mighri H, Aouni M, Gharsallah N, Kadri A. Chemical composition and in vitro evaluation of antioxidant, antimicrobial, cytotoxicity and antiacetylcholinesterase properties of Tunisian Origanum majorana L. essential oil. Microb Pathog. 2016;95:86-94.

23. Luo W, Du Z, Zheng Y, Liang X, Huang G, Zhang Q, et al. Phytochemical composition and bioactivities of essential oils from six Lamiaceae species. Ind Crop Prod. 2019;133:357-64.

24. Bounatirou S, Smiti S, Miguel M, Faleiro L, Rejeb M, Neffati M, et al. Chemica composition, antioxidant and antibacterial activities of the essential oils isolated from Tunisian Thymus capitatus Hoff. Et link. Food Chem. 2007. 105(1):146-55. 
25. Goudjil MB, Zighmi S, Hamada D, Mahcene Z, Bencheikh SE, Ladjel S. Biological activities of essential oils extracted from Thymus capitatus (Lamiaceae). South Afr J Bot. 2020;128:274-82.

26. Mejri J, Abderrabba M, Mejri M. Chemical composition of the essential oil of Ruta chalepensis L: influence of drying, hydro-distillation duration and plant parts. Ind Crop Prod. 2010;32(3):671-3.

27. Bakkali F, Averbeck S, Averbeck D, Idaomar M. Biological effects of essential oils - a review. Food Chem Toxicol. 2008;46(2):446-75.

28. Jordán MJ, Martínez RM, Goodner KL, Baldwin EA, Sotomayor JA. Seasonal variation of Thymus hyemalis Lange and Spanish Thymus vulgaris $L$. essential oils composition. Ind Crop Prod. 2006;24(3):253-63.

29. Viljoen AM, Subramoney S, van Vuuren SF, Başer KHC, Demirci B. The composition, geographical variation and antimicrobial activity of Lippia javanica (Verbenaceae) leaf essential oils. J Ethnopharmacol. 2005;96(1-2): 271-7.

30. Adams RP. Identification of essential oil components by gas chromatography/ mass spectrometry. 4th ed. Illinois: Allured publishing corporationCarol Stream; 2007.

31. Babushok VI, Linstrom PJ, Zenkevich IG. Retention indices for frequently reported compounds of plant essential oils. J Phys Chem Ref Data Monogr. 2011;40(4):043101.

32. Elaissi A, Rouis Z, Salem NAB, Mabrouk S, ben Salem Y, Salah KBH, et al. Chemical composition of 8 eucalyptus species' essential oils and the evaluation of their antibacterial, antifungal and antiviral activities. BMC Complement Altern Med. 2012;12:81.

33. NCCLS (National Committee for Clinical Laboratory Standards). Performance standards for antimicrobial susceptibility testing: Twelfth International Supplement; 2002.

34. Hersch-Martínez P, Leaños-Miranda BE, Solórzano-Santos F. Antibacterial effects of commercial essential oils over locally prevalent pathogenic strains in Mexico. Fitoterapia. 2005;76(5):453-7.

35. Ponce AG, Fritz R, del Valle C, Roura SI. Antimicrobial activity of essential oils on the native microflora of organic Swiss chard. LWT Food Sci Technol. 2003:36(7):679-84

36. Schwarz S, Silley P, Simjee S, Woodford N, van Duijkeren E, Johnson AP, et al. Editorial: assessing the antimicrobial susceptibility of bacteria obtained from animals. J Antimicrob Chemother. 2010;65(4):601-4.

37. Santos-Gomes PC, Fernandes-Ferreira M. Organ- and season-dependent variation in the essential oil composition of Salvia officinalis L. cultivated at two different sites. J Agric Food Chem. 2001:49(6):2908-16.

38. Bouaziz M, Yangui T, Sayadi S, Dhouib A. Disinfectant properties of essential oils from Salvia officinalis L. cultivated in Tunisia. Food Chem Toxicol. 2009; 47(11):2755-60.

39. Russo M, Suraci F, Postorino S, Serra D, Roccotelli A, Agosteo GE. Essential oil chemical composition and antifungal effects on Sclerotium cepivorum of Thymus capitatus wild populations from Calabria, southern Italy. Rev Bras Farm. 2013:23(2):239-48.

40. Jemaa MB, Falleh $H$, Serairi $R$, Neves MA, Snoussi M, Isoda $H$, et al. Nanoencapsulated Thymus capitatus essential oil as natural preservative. Innov Food Sci Emerg Technol. 2018;45:92-7.

41. El-Jalel LFA, Elkady WM, Gonaid MH, El-Gareeb KA. Difference in chemical composition and antimicrobial activity of Thymus capitatus L. essential oil at different altitudes. Future J Pharm Sci. 2018:4(2):156-60

42. El-Akhal F, Lalami AEO, Zoubi YE, Greche H, Guemmouh R. Chemical composition and larvicidal activity of essential oil of Origanum majorana (Lamiaceae) cultivated in Morocco against Culex pipiens (Diptera: Culicidae). Asian Pac J Trop Biomed. 2014;4(9):746-50.

43. Jardak M, Elloumi-Mseddi J, Aifa S, Mnif S. Chemical composition, antibiofilm activity and potential cytotoxic effect on cancer cells of Rosmarinus officinalis L. essential oil from Tunisia. Lipids Health Dis. 2017;16(1):190.

44. Ait-Ouazzou A, Lorán S, Bakkali M, Laglaoui A, Rota C, Herrera A, et al. Chemical composition and antimicrobial activity of essential oils of Thymus algeriensis, Eucalyptus globulus and Rosmarinus officinalis from Morocco. J Sci Food Agric. 2011;91(14):2643-51.

45. Pintore G, Usai M, Bradesi P, Juliano C, Boatto G, Tomi F, et al. Chemical composition and antimicrobial activity ofRosmarinus officinalis $L$. oils from Sardinia and Corsica. Flavour Fragr J. 2002;17(1):15-9.

46. Džamić AM, Nikolić BJ, Giweli AA, Mitić-Ćulafić DS, Soković MD, Ristić MS, et al. Libyan Thymus capitatus essential oil: antioxidant, antimicrobial, cytotoxic and colon pathogen adhesion-inhibition properties. J Appl Microbiol. 2015;119(2):389-99.
47. Veldhuizen EJA, Tjeerdsma-van Bokhoven JLM, Zweijtzer C, Burt SA, Haagsman HP. Structural requirements for the antimicrobial activity of Carvacrol. J Agric Food Chem. 2006;54(5):1874-9.

48. Ben Arfa A, Combes S, Preziosi-Belloy L, Gontard N, Chalier P. Antimicrobial activity of carvacrol related to its chemical structure. Lett Appl Microbiol. 2006;43(2):149-54.

49. Dorman HJD, Deans SG. Antimicrobial agents from plants: antibacterial activity of plant volatile oils. J Appl Microbiol. 2000;88(2):308-16.

50. Mourey A, Canillac N. Anti-listeria monocytogenes activity of essential oils components of conifers. Food Control. 2002;13(4-5):289-92.

51. Gill A, Delaquis P, Russo P, Holley R. Evaluation of antilisterial action of cilantro oil on vacuum packed ham. Int J Food Microbiol. 2002;73(1):83-92.

52. Griffin SG, Wyllie SG, Markham JL, Leach DN. The role of structure and molecular properties of terpenoids in determining their antimicrobial activity. Flavour Fragr J. 1999:14(5):322-32.

53. Van de Vel E, Sampers I, Raes K. A review on influencing factors on the minimum inhibitory concentration of essential oils. Crit Rev Food Sci Nutr. 2019;59(3):357-78.

54. Merghni A, Marzouki $H$, Hentati $H$, Aouni M, Mastouri M. Antibacterial and antibiofilm activities of Laurus nobilis L. essential oil against Staphylococcus aureus strains associated with oral infections. Curr Res Transl Med. 2016; 64(1):29-34.

55. Ouedrhiri W, Balouiri M, Bouhdid S, Moja S, Chahdi FO, Taleb M, et al. Mixture design of Origanum compactum, Origanum majorana and Thymus serpyllum essential oils: optimization of their antibacterial effect. Ind Crop Prod. 2016:89:1-9.

56. Sellami IH, Maamouri E, Chahed T, Wannes WA, Kchouk ME, Marzouk B. Effect of growth stage on the content and composition of the essential oil and phenolic fraction of sweet marjoram (Origanum majorana L.). Ind Crop Prod. 2009:30(3):395-402.

57. Elaissi A, Rouis Z, Mabrouk S, Salah KBH, Aouni M, Khouja ML, et al. Correlation between chemical composition and antibacterial activity of essential oils from fifteen eucalyptus species growing in the Korbous and Jbel Abderrahman arboreta (north East Tunisia). Molecules. 2012;17(3):3044-57.

58. Ezzeddine NBH-B, Abdelkéfi MM, Aissa RB, Chaabouni MM. Antibacterial screening of Origanum majorana L. oil from Tunisia. J Essent Oil Res. 2001;13(4):295-7.

\section{Publisher's Note}

Springer Nature remains neutral with regard to jurisdictional claims in published maps and institutional affiliations.

Ready to submit your research? Choose BMC and benefit from:

- fast, convenient online submission

- thorough peer review by experienced researchers in your field

- rapid publication on acceptance

- support for research data, including large and complex data types

- gold Open Access which fosters wider collaboration and increased citations

- maximum visibility for your research: over $100 \mathrm{M}$ website views per year

At $\mathrm{BMC}$, research is always in progress.

Learn more biomedcentral.com/submissions 